\title{
Relationship between spousal education gaps and life satisfaction: Evidence from Canada
}

\author{
Ehsan Latif* \\ Department of Economics, Thompson Rivers University, Canada
}

Received: 10 February 2017

Revised: 19 June 2017

Accepted: 19 June 2017

\begin{abstract}
This study uses Canadian data from the General Social Survey (Cycle 25:2011) to examine the impact of a spousal education gap on males' and females' life satisfaction. The study finds that a spousal education gap, whether positive or negative, does not have any significant impact on males' and females' life satisfaction. To further investigate these issues, the study divided the sample into two groups based on age categories: those below age 55 and those at or above age 55. The spousal education gap has an insignificant impact on life satisfaction in both of these groups.
\end{abstract}

Keywords: spousal education gaps; life satisfaction; Canada.

JEL Classification Codes: I20, I31, J12

\section{Introduction}

A major long-term trend in the education sector in developed countries including Canada is a narrowing of the gap in educational attainment between males and females. In Canada, the proportion of women aged 25 to 64 with a university certificate or degree grew at a faster pace than that of men, more than doubling between 1991 and 2015 from 15\% to 35\% (Table A1 in Appendix A). The majority (56\%) of students enrolled in Canada's public colleges and universities in 2013-14 were women, and women accounted for 58\% of the total number of graduates in 2013 (Ferguson, 2016). In 1981, for every 100 women aged 25 to 49 with a university degree, 157 men had a comparable education. The ratio changed to 84 men for every 100 women in 2006 (Statistics Canada, 2011).

The influx of women into higher education has changed the dynamics of marriage: Women are now less likely than men to find a partner with the same level of education. A substantial number of studies, primarily using data from the United States, have examined marital outcomes for couples in which wives have more education than their husbands; the majority of

\footnotetext{
*E-mail: elatif@tru.ca.

Citation: Latif, E. (2017) Relationship between spousal education gaps and life satisfaction: Evidence from Canada, Economics and Business Letters, 6(3), 69-80.
} 
these studies showed that such marriages were more likely to dissolve (Kalmijn, 2003; Goldstein \& Harknett, 2006; Phillips \& Sweeney, 2006). On the other hand, in a recent study using data from the United States, Schwartz \& Han (2014) concluded that couples that married in the early 1990s were among the first for whom wives' educational advantage was no longer associated with a higher risk of divorce. All of these studies focused on the relationship between spousal education gap and marital outcomes; however, very little research has examined the impact of spousal education gap on life satisfaction or happiness (Groot \& Van Den Brink, 2002; Garcia et al., 2010). In recent times, the economics of happiness has been flourishing, and results of these studies have important policy implications (Stutzer \& Frey, 2012). The objective of this study is to use Canadian data to examine the relationship between spousal education gap and life satisfaction. In this way, this study aims to contribute to the burgeoning economics of happiness literature.

A study by Groot \& Van Den Brink (2002) is most closely related to this study. In their study, Groot \& Van Den Brink (2002) analysed whether differences in age and education between spouses had an effect on happiness. The study found that a positive age gap between husband and wife increased life satisfaction of both males and females. On the other hand, absolute education gap had a positive effect on female life satisfaction, whereas such a gap had no statistically significant impact on male life satisfaction. In a related study, Garcia et al. (2010) examined the effects of both own and spouse's education levels on individual economic satisfaction for European households. The results showed that, in the majority of European countries, male and female income satisfaction significantly increased when the husband achieved higher education qualifications. On the other hand, in a limited number of countries, the wife's higher education had a positive effect on female income satisfaction.

In a sociological study, Schwartz \& Han (2014) used data from the United States to examine trends in the relationship between spouses' relative education and marital dissolution among recent marriage cohorts in which women's education clearly exceeded men's. This study noted that wives who had more education than their husbands were at one time more likely to divorce than other women. Using data on marriages formed between 1950 and 2004 in the United States, this study showed a large shift in the association between spouses' relative education and marital dissolution. The study concluded that couples who married in the early 1990s were among the first for whom wives' educational advantage was no longer associated with a higher risk of divorce. The study also found an increase in the relative stability of marriages between educational equals.

This study aims to make couple of empirical contributions to the economics of happiness literature:

- This will be the first study to use Canadian data to examine the relationship between spousal educational gap and life satisfaction.

- This study examines the relationship between spousal educational gap and life satisfaction for subsamples based on age, with categories of those below age 55 and those aged greater than or equal to 55, to see whether the relationship differs between these two age groups. As suggested in Schwartz \& Han (2014), there has been a large shift in the association between spouses' relative education and marital dissolution. In particular, the couples who married in the early 1990s were among the first for whom wives' educational advantage was no longer associated with a higher risk of divorce. This study assumes that there has been also shift in the association between spouses' relative education and individuals' life satisfaction. The relationship for the younger generation may be different from the relationship for the older generation. This study categorizes individuals aged 55 or more as older generation while individuals aged below 55 as younger generation. 
The paper is structured in following way: Section 2 deals with data and empirical methodology; Section 3 discusses results of the study; and Section 4 is the concluding section.

\section{Data}

This study uses Canadian data from the General Social Survey-2011 (GSS-Cycle 25). This survey collected detailed information on changes in Canadian families. Topics of this survey include conjugal and parental history, family origins, work history, respondent's main activity, education, and other socio-economic characteristics. The target population for cycle 25 was all persons 15 years of age and older in Canada, excluding residents of the Yukon, Northwest Territories, and Nunavut, and full-time residents of institutions. Data for this survey were collected from February to November 2011. The sample size for this study is 8,407.

The dependent variable of this study is life satisfaction. This variable is determined based on responses to the following question: "Using a scale of 0 to 10 , where 0 means "Very dissatisfied' and 10 means 'Very satisfied,' how do you feel about your life as a whole?"

The major covariate of interest is the education gap between husband and wife. This covariate is represented by the following two dummy variables: whether the respondent has more education than his or her spouse (positive education gap) and whether the respondent has less education than his or her spouse (negative education gap). The base category is the same level of education for both husband and wife. This study also includes age, squared age, own education, health status, spousal work status, home ownership, household income, and province of residence.

\section{Conceptual framework}

There are number of ways through which differences in the educational attainment of husbands and wives may impact spousal life satisfaction. It is argued that women's higher educational status than their male partners may pose a significant threat to men's gender identity as breadwinners and as the "head of the household" (Tichenor, 2005). Consequently, wife's higher educational status may lower husband's life satisfaction. On the other hand, the social equality hypothesis postulates that no gap or a small spousal gap in education is associated with higher marital stability and happiness among couples (Weis \& Willis, 1997; Spitze \& South, 1985). In particular, homogamous couples with regard to education and social status are expected to share values and beliefs that facilitate a supportive relationship (Stutzer et al., 2006).

\section{Empirical framework}

Individual life satisfaction is not observable. However, the discrete ordered categorical variable life satisfaction can be observed. Because of the ordinal nature of the dependent variable, life satisfaction $(L S)$, an ordered probit method is used to derive a life satisfaction equation. The latent dependent variable life satisfaction $\left(L S^{*}\right)$ is described in the following way:

$$
L S_{i}^{*}=\beta_{1} X+\beta_{2} Z+\varepsilon
$$

where $X$ is a vector of observable individual-specific explanatory variables, such as gender, age, education, spousal age gap, housing wealth, health and employment status; $Z$ represents spousal education gap; and $\varepsilon$ is the error term.

\section{Empirical framework}

Table 1 provides a frequency distribution of the life satisfaction variable for males and females. The table shows that females have higher mean life satisfaction than males. Like most other 
studies on happiness and well-being, this study also shows that the frequency distribution of life satisfaction is highly skewed to the right. Tables $2 \& 3$ show descriptive statistics of some important variables for males and females respectively. Some highlights of Table 2 and Table 3 are as follows: on average, male spouses are older than female spouses; $33 \%$ of males have a higher level of education than their spouses, while the corresponding figure is $36 \%$ for females; $25 \%$ of males have a lower level of education than their spouses, while the corresponding figure is $22 \%$ for females; $63 \%$ of males and $14 \%$ of females are older than their spouses; and $15 \%$ of males and $64 \%$ of females are younger than their spouses.

Table 4 provides data on average life satisfaction by gender based on spousal differences in education and age. The table shows that males with a lower level of education than their spouses are happier than males with either the same or a higher level of education than their spouses. On the other hand, females with the same level of education as their spouses are, on average, happier than females who are either less or more educated than their spouses. In the case of age difference, both males and females are, on average, happier if there is no age difference between husband and wife. However, females are, on average, happier when they are younger than their spouses than when they are older than their spouses. On the other hand, males are, on average, happier when they are older than their spouses compared to when they are younger than their spouses. However, $\mathrm{t}$ tests for mean difference did not find any significant difference in happiness levels between males and females except with respect to category 'Younger than spouse'.

Table 1. Frequency distribution of life satisfaction, by gender

\begin{tabular}{lrr}
\hline \hline & Male (\%) & Female (\%) \\
\hline \hline Less than or equal 4 & 1.24 & 1.28 \\
5 & 2.55 & 2.85 \\
6 & 3.41 & 2.78 \\
7 & 12.15 & 12.02 \\
8 & 32.82 & 31.11 \\
9 & 22.50 & 20.26 \\
10 & 25.33 & 29.71 \\
Average life satisfaction & 8.40 & 8.47 \\
\hline \hline
\end{tabular}

Table 2. Descriptive Statistics of selected explanatory variables (Male)

\begin{tabular}{lrrrr}
\hline \hline & Mean & $\begin{array}{c}\text { Standard } \\
\text { Deviation }\end{array}$ & Maximum & Minimum \\
\hline \hline Age (years) & 53.45 & 14.16 & 80 & 19 \\
Years of Education & 20.67 & 3.12 & 16 & 25 \\
Excellent Health & .209 & .406 & 1 & 0 \\
Very Good Health & .374 & .484 & 1 & 0 \\
Good Health & .289 & .453 & 1 & 0 \\
Fair Health & .097 & .269 & 1 & 0 \\
Poor Health & .029 & .169 & 1 & 0 \\
Higher level of education than spouse & .332 & .471 & 1 & 0 \\
Lower level of education than spouse & .249 & .433 & 1 & 0 \\
Both have the same level of education & .418 & .493 & 1 & 0 \\
Older than spouse & .629 & .483 & 1 & 0 \\
Younger than spouse & .148 & .355 & 1 & 0 \\
Both are of the same age & .223 & .416 & 1 & 0 \\
Sample Size & 4,196 & & & \\
\hline \hline
\end{tabular}


Table 3. Descriptive Statistics of selected explanatory variables (Female)

\begin{tabular}{lrrrr}
\hline \hline & Mean & $\begin{array}{c}\text { Standard } \\
\text { Deviation }\end{array}$ & Maximum & Minimum \\
\hline \hline Age (years) & 50.31 & 13.43 & 80 & 21 \\
Years of Education & 20.81 & 3.05 & 25 & 16 \\
Excellent Health & .222 & .416 & 1 & 0 \\
Very Good Health & .374 & .484 & 1 & 0 \\
Good Health & .289 & .453 & 1 & 0 \\
Fair Health & .083 & .275 & 1 & 0 \\
Poor Health & .031 & .173 & 1 & 0 \\
Higher level of education than spouse & .358 & .479 & 1 & 0 \\
Lower level of education than spouse & .223 & .416 & 1 & 0 \\
Both have the same level of education & .418 & .493 & 1 & 0 \\
Older than spouse & .142 & .349 & 1 & 0 \\
Younger than spouse & .644 & .478 & 1 & 0 \\
Both are of the same age & .214 & .409 & 1 & 0 \\
Sample Size & 4,211 & & & \\
\hline \hline
\end{tabular}

Table 4. Average life satisfaction, by gender

\begin{tabular}{lrr}
\hline \hline & Male & Female \\
\hline \hline Higher level of education & 8.36 & 8.42 \\
than spouse & $(.037)$ & $(.036)$ \\
Both have the same level & 8.4 & 8.51 \\
of education & $(.033)$ & $(.033)$ \\
Lower level of education & 8.43 & 8.47 \\
than spouse & $(.042)$ & $(.049)$ \\
Older than spouse & 8.37 & 8.37 \\
& $(.028)$ & $(.064)$ \\
Both are of the same age & 8.50 & 8.55 \\
& $(.042)$ & $(.044)$ \\
Younger than spouse & 8.33 & 8.46 \\
& $(.056)$ & $(.027)$ \\
\hline \hline
\end{tabular}

Notes: Standard errors are shown in the parentheses.

Table 5 shows the results of regressions that include relevant variables that influence life satisfaction. The results for the male sample are shown in the second column of Table 5. The results suggest that an education gap, whether positive or negative, has no effect on life satisfaction. Being older than their spouses also has no effect on males' life satisfaction. However, spousal employment has a significant negative effect on males' life satisfaction. Other results of the model are as follows: age has u-shaped effect on life satisfaction; health positively affects life satisfaction; being unemployed has a negative effect on life satisfaction; and home ownership and household income positively affect life satisfaction. The third column of Table 5 shows the results for the female sample. The results show that a spousal education gap, whether positive or negative, has no significant effect on females' life satisfaction. However, being older than their spouses negatively affects females' life satisfaction. Other results of this model are qualitatively similar to the findings from the male sample with the exception of 'own education'. In the female sample, the variable 'own education' has a significant negative effect on life satisfaction. This result is consistent with the finding from Clark \& Oswald (1996).Usually highly educated people have higher job expectations which are more difficult to fulfill and such failure reduces life satisfaction (Clark \& Oswald, 1996). 
Table 5. Regression results (Overall model)

\begin{tabular}{lrr}
\hline \hline & Male Sample & Female Sample \\
\hline \hline Age & $-0.055^{*}$ & $-0.048^{*}$ \\
Squared Age & $(0.009)$ & $(0.009)$ \\
& $0.0006^{*}$ & $0.0006^{*}$ \\
Excellent Health & $(0.00008)$ & $(0.00009)$ \\
& $1.218^{*}$ & $1.517^{*}$ \\
Very Good Health & $(0.137)$ & $(0.129)$ \\
& $0.833^{*}$ & $1.100^{*}$ \\
Good Health & $(0.133)$ & $(0.126)$ \\
& $0.513^{*}$ & $0.725^{*}$ \\
Fair Health & $(0.133)$ & $(0.124)$ \\
& $0.284^{* *}$ & $0.423^{*}$ \\
Unemployed & $(0.140)$ & $(0.125)$ \\
& $-0.281^{* *}$ & $-0.335^{* * *}$ \\
Home Ownership & $(0.150)$ & $(0.202)$ \\
& $0.206^{*}$ & $0.116^{* *}$ \\
Own Education (Years) & $(0.064)$ & $(0.060)$ \\
& -0.008 & $-0.017^{*}$ \\
Positive Education Gap & $(0.006)$ & $(0.006)$ \\
& -0.013 & -0.045 \\
Negative Education Gap & $(0.038)$ & $(0.037)$ \\
& 0.075 & -0.041 \\
Positive Age Gap & $(0.046)$ & $(0.046)$ \\
& -0.041 & $-0.084^{* * *}$ \\
Household Income & $(0.034)$ & $(0.048)$ \\
Spouse Working & $0.321^{*}$ & $0.218^{*}$ \\
Pseudo R & $(0.047)$ & $(0.047)$ \\
Number of observation & $-0.083^{* *}$ & 0.074 \\
\hline \hline
\end{tabular}

Notes: Standard Errors are shown in the parentheses. The models also include provincial dummies. *, **, and *** indicate that the coefficient is significant at the $1 \%, 5 \%$, and $10 \%$ levels, respectively.

The marginal effects of ordered probit models for males and females are shown in Table 9 and Table 10 respectively. Marginal effects show the change in probability when a binary independent variable changes from 0 to 1 . The results show that, for both male and female samples, the marginal effects of 'Positive Education Gap' and 'Negative Education Gap' are not significant for different categories of the dependent variable ${ }^{1}$.

To further investigate this issue, the study divided the sample into two groups based on age: individuals below 55 and individuals at or above 55. The study estimated the regressions for males and females belonging to both age categories. The results of these regressions are shown in Table 6 . The second column of Table 6 provides the results of the male sample aged less than 55, which show that neither a positive nor a negative spousal education gap has any association with males' life satisfaction. Furthermore, neither being older than their spouses nor their spouses' employment has a significant effect on males' life satisfaction. The results of the female sample aged less than 55 are shown in the third column of Table 6 .The results show

\footnotetext{
${ }^{1}$ To save space, only marginal effects of 'Positive Education Gap' and 'Negative Education Gap' are shown in Table 8 and Table 9.
} 
that being older than their spouses has no significant effect on females' life satisfaction. Finally, having a working spouse positively affects females' life satisfaction. The results for the individuals aged 55 or greater are shown in the fourth and fifth columns of Table 6 . The results of the male sample, as shown in the fourth column, suggest that spousal education gap and spousal age gap has no significant effect on males' life satisfaction. However, having a working spouse negatively affects males' life satisfaction. The fifth column of Table 6 provides the results of the female sample aged 55 or more. In this sample, education gap, whether positive or negative, has no effect on females' life satisfaction. However, being older than their spouses has a significant negative effect on females' life satisfaction.

Table 6. Regression results (Subgroup analyses)

\begin{tabular}{|c|c|c|c|c|}
\hline & $\begin{array}{r}\text { Male } \\
\text { Sample } \\
\text { Age }<55 \\
\end{array}$ & $\begin{array}{r}\text { Female } \\
\text { Sample } \\
\text { Age }<55 \\
\end{array}$ & $\begin{array}{r}\text { Male } \\
\text { Sample } \\
\text { Age } \geq 55 \\
\end{array}$ & $\begin{array}{l}\text { Female } \\
\text { Sample } \\
\text { Age } \geq 55\end{array}$ \\
\hline Age & $\begin{array}{c}-0.116^{*} \\
(0.030)\end{array}$ & $\begin{array}{c}-0.108 * \\
(0.028)\end{array}$ & $\begin{array}{r}0.038 \\
(0.062)\end{array}$ & $\begin{array}{r}0.065 \\
(0.076)\end{array}$ \\
\hline Squared Age & $\begin{array}{r}0.001 * \\
(0.0003)\end{array}$ & $\begin{array}{r}0.001 * \\
(0.0003)\end{array}$ & $\begin{array}{r}-0.0001 \\
(0.0004)\end{array}$ & $\begin{array}{r}-0.0003 \\
(0.0005)\end{array}$ \\
\hline Excellent Health & $\begin{array}{l}1.606^{*} \\
(0.312)\end{array}$ & $\begin{array}{l}1.551^{*} \\
(0.199)\end{array}$ & $\begin{array}{l}1.103 * \\
(0.052)\end{array}$ & $\begin{array}{l}1.439 * \\
(0.170)\end{array}$ \\
\hline Very Good Health & $\begin{array}{l}1.181^{*} \\
(0.306)\end{array}$ & $\begin{array}{l}1.095 \% \\
(0.195)\end{array}$ & $\begin{array}{c}0.707 * \\
(0.146)\end{array}$ & $\begin{array}{l}1.090^{*} \\
(0.162)\end{array}$ \\
\hline Good Health & $\begin{array}{l}0.861 * \\
(0.307)\end{array}$ & $\begin{array}{l}0.660 * \\
(0.195)\end{array}$ & $\begin{array}{l}0.395 * \\
(0.146)\end{array}$ & $\begin{array}{l}0.783^{*} \\
(0.158)\end{array}$ \\
\hline Fair Health & $\begin{array}{r}0.567 * * * \\
(0.318)\end{array}$ & $\begin{array}{r}0.451 * * \\
(0.211)\end{array}$ & $\begin{array}{r}0.201 \\
(0.157)\end{array}$ & $\begin{array}{l}0.399 * \\
(0.169)\end{array}$ \\
\hline Unemployed & $\begin{array}{r}-0.243 \\
(0.185)\end{array}$ & $\begin{array}{r}-0.396 * * * \\
(0.221)\end{array}$ & $\begin{array}{l}-0.337 \\
(0.266)\end{array}$ & $\begin{array}{c}-0.215^{*} \\
(0.556)\end{array}$ \\
\hline Home Ownership & $\begin{array}{l}0.207 * \\
(0.086)\end{array}$ & $\begin{array}{r}0.139 * * * \\
(0.077)\end{array}$ & $\begin{array}{r}0.165 \\
(0.102)\end{array}$ & $\begin{array}{r}0.050 \\
(0.098)\end{array}$ \\
\hline Own Education (Years) & $\begin{array}{r}-0.016^{* * *} * \\
(0.009)\end{array}$ & $\begin{array}{r}-0.018 * * \\
(0.009)\end{array}$ & $\begin{array}{r}0.009 \\
(0.009)\end{array}$ & $\begin{array}{r}-0.018 * * * \\
(0.010)\end{array}$ \\
\hline Positive Education Gap & $\begin{array}{r}0.020 \\
(0.054)\end{array}$ & $\begin{array}{r}-0.078 \\
(0.049)\end{array}$ & $\begin{array}{r}-0.051 \\
(0.054)\end{array}$ & $\begin{array}{r}-0.013 \\
(0.064)\end{array}$ \\
\hline Negative Education Gap & $\begin{array}{r}0.074 \\
(0.065)\end{array}$ & $\begin{array}{l}-0.055 \\
(0.063)\end{array}$ & $\begin{array}{r}0.070 \\
(0.067)\end{array}$ & $\begin{array}{c}-0.044 \\
(0.070)\end{array}$ \\
\hline Positive Age Gap & $\begin{array}{r}-0.027 \\
(0.047)\end{array}$ & $\begin{array}{r}0.002 \\
(0.065)\end{array}$ & $\begin{array}{r}-0.036 \\
(0.051)\end{array}$ & $\begin{array}{r}-0.155^{* *} \\
(0.074)\end{array}$ \\
\hline Spouse Working & $\begin{array}{r}0.006 \\
(0.051)\end{array}$ & $\begin{array}{l}0.228 * \\
(0.083)\end{array}$ & $\begin{array}{r}-0.187 * \\
(0.056)\end{array}$ & $\begin{array}{r}0.007 \\
(0.064)\end{array}$ \\
\hline Household Income & $\begin{array}{l}0.350^{*} \\
(0.069)\end{array}$ & $\begin{array}{l}0.203^{*} \\
(0.063)\end{array}$ & $\begin{array}{l}0.324 * \\
(0.066)\end{array}$ & $\begin{array}{l}0.256^{*} \\
(0.080)\end{array}$ \\
\hline Pseudo $\mathrm{R}^{2}$ & 0.0461 & 0.0526 & 0.0428 & 0.0467 \\
\hline Number of observation & 2,144 & 2,535 & 2,052 & 1,676 \\
\hline
\end{tabular}

Notes: Standard Errors are shown in the parentheses. The models also include provincial dummies. *, **, and *** indicate that the coefficient is significant at the $1 \%, 5 \%$, and $10 \%$ levels, respectively.

In sum, the results based on age groups suggest that spousal education gap has no significant effect on females' or males' life satisfaction. However, being older than their spouses negatively affects life satisfaction of females aged 55 and older. Finally, having a working spouse has a negative effect on the life satisfaction of males aged 55 and older. 
Table 7. Regression results (Overall model)

\begin{tabular}{lrr}
\hline \hline & Male Sample & Female Sample \\
\hline \hline Age & $-0.054^{*}$ & $-0.048^{*}$ \\
Squared Age & $(0.009)$ & $(0.009)$ \\
& $0.0006^{*}$ & $0.0006^{*}$ \\
Excellent Health & $(0.00008)$ & $(0.00009)$ \\
& $1.215^{*}$ & $1.516^{*}$ \\
Very Good Health & $(0.137)$ & $(0.129)$ \\
& $0.832^{*}$ & $1.100^{*}$ \\
Good Health & $(0.134)$ & $(0.126)$ \\
& $0.511^{*}$ & $0.725^{*}$ \\
Fair Health & $(0.133)$ & $(0.124)$ \\
& $0.282^{* *}$ & $0.423^{*}$ \\
Unemployed & $(0.141)$ & $(0.124)$ \\
& $-0.288^{* *}$ & -0.331 \\
Home Ownership & $(0.150)$ & $(0.202)$ \\
& $0.200^{*}$ & $0.116^{* *}$ \\
Own Education (Years) & $(0.064)$ & $(0.060)$ \\
& -0.005 & $-0.017^{*}$ \\
Education Gap & $(0.006)$ & $(0.006)$ \\
Positive Age Gap & -0.005 & -0.001 \\
Household Income & $(0.006)$ & $(0.006)$ \\
Spouse Working & -0.040 & $-0.084^{* * *}$ \\
Pseudo R & $(0.034)$ & $(0.048)$ \\
Number of observation & $0.314^{*}$ & $0.219^{*}$ \\
\hline \hline & $(0.047)$ & $(0.047)$ \\
are shown in & $-0.084^{* *}$ & 0.074 \\
& $(0.038)$ & $(0.050)$ \\
& 0.0447 & 0.0476 \\
& 4,196 & 4,211 \\
\hline
\end{tabular}

Notes: Standard Errors are shown in the parentheses. The models also include provincial dummies. *, **, and *** indicate that the coefficient is significant at the $1 \%, 5 \%$, and $10 \%$ levels, respectively.

As further robustness check, the study estimated the difference in the years of schooling and used this variable replacing 'Positive Education Gap' and 'Negative Education Gap'. The results of regressions are shown in Table 7 and Table 8 . The results are qualitatively similar to regressions shown in Table 4 and Table 5.

\section{Conclusion}

This study uses Canadian data from the General Social Survey (Cycle 25:2011) to examine the effect of a spousal education gap on males' and females' life satisfaction. The study finds that a spousal education gap, whether positive or negative, does not have any significant effect on males' and females' life satisfaction. The study further finds that having a working spouse negatively affects the life satisfaction of males, and being older than their spouses has a significant negative effect on the life satisfaction of females. To further investigate these issues, the study divided the sample into two groups based on age categories: those below age 55 and those at or above age 55. The spousal education gap has an insignificant effect on life satisfaction in both of these groups. The results from these subsamples further suggest that having a working spouse negatively affects life satisfaction only for males in the older age group (55 and over), while being older than their spouses has a negative effect on life satisfaction only for females belonging to the older age group. 
Table 8. Regression results Regression results (Subgroup analyses)

\begin{tabular}{lrrrr}
\hline \hline & Male & Female & Male & Female \\
& Sample & Sample & Sample & Sample \\
Age $<55$ & Age $<55$ & Age $\geq 55$ & Age $\geq 55$ \\
\hline \hline Age & $-0.116^{*}$ & $-0.107^{*}$ & 0.038 & 0.068 \\
& $(0.030)$ & $(0.028)$ & $(0.062)$ & $(0.076)$ \\
Squared Age & & & & \\
& $0.001^{*}$ & $0.001^{*}$ & -0.0001 & -0.0003 \\
Excellent Health & $(0.0003)$ & $(0.0003)$ & $(0.0004)$ & $(0.0005)$ \\
& $1.600^{*}$ & $1.551^{*}$ & $1.033^{*}$ & $1.439^{*}$ \\
Very Good Health & $(0.311)$ & $(0.199)$ & $(0.152)$ & $(0.169)$ \\
& $1.178^{*}$ & $1.099^{*}$ & $0.707^{*}$ & $1.089^{*}$ \\
Good Health & $(0.306)$ & $(0.195)$ & $(0.146)$ & $(0.163)$ \\
& $0.857^{*}$ & $0.664^{*}$ & $0.394^{*}$ & $0.781^{*}$ \\
Fair Health & $(0.307)$ & $(0.195)$ & $(0.144)$ & $(0.158)$ \\
& $0.569^{* * *}$ & $0.455^{* *}$ & 0.197 & $0.397^{*}$ \\
Unemployed & $(0.318)$ & $(0.211)$ & $(0.155)$ & $(0.169)$ \\
& -0.256 & $-0.383^{* * *}$ & -0.345 & -0.224 \\
Home Ownership & $(0.186)$ & $(0.221)$ & $(0.265)$ & $(0.553)$ \\
& $0.207^{*}$ & $0.141^{* * *}$ & 0.164 & 0.047 \\
Own Education (Years) & $(0.085)$ & $(0.077)$ & $(0.102)$ & $(0.098)$ \\
& -0.014 & -0.013 & 0.003 & $-0.020^{* * *}$ \\
Education Gap & $(0.009)$ & $(0.009)$ & $(0.009)$ & $(0.010)$ \\
& -0.013 & -0.008 & -0.016 & 0.007 \\
Positive Age Gap & $(0.008)$ & $(0.008)$ & $(0.008)$ & $(0.009)$ \\
Spouse Working & -0.026 & 0.001 & -0.036 & $-0.154^{* *}$ \\
Household Income & $(0.047)$ & $(0.073)$ & $(0.050)$ & $(0.074)$ \\
& -0.001 & $0.227^{*}$ & $-0.187^{*}$ & 0.008 \\
Pseudo R & $(0.051)$ & $(0.083)$ & $(0.056)$ & $(0.064)$ \\
Number of observation & $0.339^{*}$ & $0.201^{*}$ & $0.319^{*}$ & $0.267^{*}$ \\
\hline \hline & $(0.070)$ & $(0.060)$ & $(0.067)$ & $(0.080)$ \\
& 0.0462 & 0.0524 & 0.0428 & 0.0468 \\
& 2,144 & 2,535 & 2,052 & 1,676 \\
\hline
\end{tabular}

Notes: Standard Errors are shown in the parentheses. The models also include provincial dummies. *, **, and *** indicate that the coefficient is significant at the $1 \%, 5 \%$, and $10 \%$ levels, respectively.

The finding that spousal education gap has no effect on males' life satisfaction is in conformity with the findings of Groot \& Van Den Brink (2002). However, the finding that spousal education gap has no effect on females' life satisfaction contradicts Groot and Van Den Brink (2002), who found that a positive education gap between husband and wife actually increased females' life satisfaction. Different time framework for the samples of the two studies may be the reason for such difference in the findings. Beginning in the mid-1990s women's college completion rates began to surpass men's in Canada and as a result Canada is now experiencing reversal of the gender gap in education (Table A1 in Appendix A). It is found that wives have more education than their husbands in almost all countries in which the gender gap in education has reversed (Esteve et al., 2012). It may be possible that attitudes toward spousal education gap has changed in recent period in Canada and females are now indifferent as to whether they have better education than their husbands or their husbands have better education than them. This study's finding that a positive age gap between husband and wife increases females' life satisfaction is similar to the result from Groot \& Van Den Brink (2002). However, it is noted here that in this study this finding is relevant particularly for the older age 
group, while Groot \& Van Den Brink (2002) did not show a result for the older subsample. The finding that having a working spouse negatively affects males' happiness is similar to the findings from a number of studies (Crompton \& Lyonette, 2005; Haller \& Hadler, 2005). However, again, it is noted that in this study such a finding is relevant for the older age group, while other studies did not distinguish between older and younger age groups.

Recently, Canadian women's participation in post-secondary education has increased, leading to a positive gap between females and males with post-secondary degrees. At the same time, the gap in the employment rate between males and females continues to decrease as more and more Canadian women enter the labor market (Table A2 in Appendix A). The good news is that this study shows that the spousal gap in education has no effect on individuals' life satisfaction. The study further finds that having a working spouse does not have any negative effect on the life satisfaction of relatively younger Canadian males aged less than 55 .

This study has a number of limitations involving endogeneity issues. There is possible reverse causality between life satisfaction and health. Further, the education gap between husbands and wives is endogenous since men who prefer wives with more education than themselves may be intrinsically more confident and happy to begin with. Unfortunately, crosssectional nature of data used in this study does not allow dealing with these issues.

Future studies may use panel data to control for unobserved individual-specific heterogeneity influencing life satisfaction. Further studies are needed, using data from both developed and developing countries.

Table 9. Marginal effects of estimated ordered probit model (Male sample)

\begin{tabular}{rrrrrrrrrrrr}
\hline \hline & $S T=0$ & $S T=1$ & $S T=2$ & $S T=3$ & $S T=4$ & $S T=5$ & $S T=6$ & $S T=7$ & $S T=8$ & $S T=9$ & $S T=10$ \\
\hline \hline PEG & .00003 & .00003 & .00002 & .00006 & .0001 & .0005 & .0006 & .0018 & .0018 & -.0011 & -.0040 \\
& $(.00009)$ & $(.0001)$ & $(.00006)$ & $(.0002)$ & $(.0003)$ & $(.0016)$ & $(.0019)$ & $(.0056)$ & $(.0053)$ & $(.0034)$ & $(.0117)$ \\
NEG & -.0001 & -.0001 & -.0001 & -.0003 & -.0006 & -.0030 & -.0038 & -.0109 & -.0109 & .0065 & .0235 \\
& $(.0001)$ & $(.0001)$ & $(.00008)$ & $(.0002)$ & $(.0004)$ & $(.0018)$ & $(.0023)$ & $(.0066)$ & $(.0069)$ & $(.0038)$ & $(.0146)$ \\
\hline \hline
\end{tabular}

Notes: PEG: Positive Education Gap; NEG: Negative Education Gap; ST: Life Satisfaction; The full model includes other variables: age, health, education, homeownership, age gap with spouse, spouse's work status, household income and provinces.

Table 10. Marginal effects of estimated ordered probit model (Female sample)

\begin{tabular}{rrrrrrrrrrrr}
\hline \hline & $S T=0$ & $S T=1$ & $S T=2$ & $S T=3$ & $S T=4$ & $S T=5$ & $S T=6$ & $S T=7$ & $S T=8$ & $S T=9$ & $S T=10$ \\
\hline \hline PEG & .00007 & .0001 & .00008 & .00016 & .0004 & .0021 & .0019 & .0066 & .0066 & -.0029 & -.0053 \\
& $(.00007)$ & $(.0001)$ & $(.00008)$ & $(.00015)$ & $(.0004)$ & $(.0018)$ & $(.0016)$ & $(.0056)$ & $(.0053)$ & $(.0024)$ & $(.0125)$ \\
NEG & .00006 & .00009 & .00007 & .00015 & .0004 & .0019 & .0017 & .0059 & .0058 & -.0026 & -.0137 \\
& $(.00009)$ & $(.0001)$ & $(.00009)$ & $(.00018)$ & $(.0005)$ & $(.0022)$ & $(.0020)$ & $(.0068)$ & $(.0065)$ & $(.0031)$ & $(.0155)$ \\
\hline \hline
\end{tabular}

Notes: PEG: Positive Education Gap; NEG: Negative Education Gap; ST: Life Satisfaction; The full model includes other variables: age, health, education, homeownership, age gap with spouse, spouse's work status, household income and provinces.

\section{References}

Clark, A.E., and Oswald, A.J. (1996) Satisfaction and comparison income, Journal of Public Economics, 61(3), 359-381.

Crompton, R., and Lyonette, C. (2005) The new gender essentialism-domestic and family 'choices' and their relation to attitudes, British Journal of Sociology, 56(4), 601-620.

Esteve, A., García-Román, J., and Permanyer, I. (2012) The Gender-Gap Reversal in Education and Its Effect on Union Formation: The End of Hypergamy?, Population and Development Review, 38(3), 535-546. 
Ferguson, S.J. (2016). Women and Education: Qualifications, Skills and Technology, Women in Canada: A Gender-based Statistical Report, Catalogue no. 89-503-X, Statistics Canada.

Garcia, I., Molina, J.A., and Navarro, M. (2010) The effects of education on spouses' satisfaction in Europe, Applied Economics, 42(28), 3607-3618.

Goldstein, J. R., and Harknett, K. (2006) Parenting across racial and class lines: Assortative mating patterns of new parents who are married, cohabiting, dating or no longer romantically involved, Social Forces, 85(1), 121-143.

Groot, W., and Van Den Brink, H M. (2002) Age and education differences in marriages and their effects on life satisfaction, Journal of Happiness Studies, 3(2), 153-165.

Haller, M., and Hadler, M. (2006) How social relations and structures can produce happiness and unhappiness: An international comparative analysis, Social Indicators Research, 75(2), 169-216.

Kalmijn, M. (2003) Union disruption in the Netherlands: Opposing influences of task specialization and assortative mating?, International Journal of Sociology, 36-64.

Milan, A. (2013) Marital status: Overview, 2011, Report on the Demographic Situation in Canada, Catalogue no. 91-209-X, Statistics Canada.

Phillips, J.A. and Sweeney, M.M. (2006) Can differential exposure to risk factors explain recent racial and ethnic variation in marital disruption?, Social Science Research, 35(2), 409434.

Schwartz, C.R., and Han, H. (2014) The reversal of the gender gap in education and trends in marital dissolution, American Sociological Review, 79(4), 605-629.

Spitze, G. and South, S.J. (1985) Women's employment, time expenditure, and divorce, Journal of Family Issues, 6(3), 307-329.

Statistics Canada (2011) General Social Survey, Cycle 25, 2011 [Canada]: Family [public use microdata file], Ottawa, Ontario, Statistics Canada.

Stutzer, A. and Frey, B.S. (2012) Recent developments in the economics of happiness: A selective overview, Recent Developments in the Economics of Happiness: A Selective Overview, IZA Discussion Paper, 7078.

Statistics Canada (2011) Families, households and housing, Canada Year Book, Ottawa, Ontario: Statistics Canada.

Udry, J. R. and Eckland, B.K. (1984) Benefits of being attractive: Differential payoffs for men and women, Psychological Reports, 54(1), 47-56.

Stutzer, A. and Frey, B.S. (2006) Does marriage make people happy, or do happy people get married?, Journal of Socio-Economics, 35(2), 326-347.

Tichenor, V.J. (2005) Earning more and getting less: Why successful wives can't buy equality, Rutgers University Press.

Weiss, Y. and Willis, R.J. (1997) Match quality, new information, and marital dissolution, Journal of Labor Economics, S293-S329. 


\section{Appendix A}

\section{Supplementary tables}

Table A1. Distribution of women and men aged 25 to 64 by highest education level attained

\begin{tabular}{lrrrrrr}
\hline Women & 1991 & 1996 & 2001 & 2006 & 2011 & 2015 \\
\hline \hline No certificate, diploma or degree & 31 & 24 & 19 & 15 & 11 & 9 \\
High school diploma or equivalent & 31 & 30 & 28 & 26 & 25 & 23 \\
Trades certificate & 10 & 9 & 9 & 9 & 8 & 7 \\
College diploma & 14 & 19 & 21 & 23 & 25 & 26 \\
University certificate, diploma or degree & 15 & 19 & 23 & 27 & 31 & 35 \\
\hline \hline Men & 1991 & 1996 & 2001 & 2006 & 2011 & 2015 \\
\hline \hline No certificate, diploma or degree & 31 & 25 & 20 & 16 & 13 & 11 \\
High school diploma & 26 & 25 & 26 & 25 & 25 & 25 \\
Trades certificate & 14 & 15 & 16 & 15 & 16 & 15 \\
College diploma & 9 & 13 & 15 & 17 & 18 & 19 \\
University certificate, diploma or degree & 19 & 21 & 24 & 26 & 28 & 30 \\
\hline \hline
\end{tabular}

Source: Statistics Canada, Labour Force Survey, annual average, 1991, 1996, 2001, 2006, 2011, 2015. The table is taken from Sarah Jane Ferguson (2016).

Table A2. Employment rate, by gender (Age $15+$ )

\begin{tabular}{|c|c|c|}
\hline Year & Male & Female \\
\hline 1980 & 72.8 & 46.4 \\
\hline 1981 & 72.8 & 47.7 \\
\hline 1982 & 68.4 & 46.5 \\
\hline 1983 & 67.4 & 46.8 \\
\hline 1984 & 68 & 47.7 \\
\hline 1985 & 68.7 & 49.1 \\
\hline 1986 & 69.6 & 50.3 \\
\hline 1987 & 70.3 & 51.3 \\
\hline 1988 & 70.9 & 52.7 \\
\hline 1989 & 71.1 & 53.6 \\
\hline 1990 & 69.9 & 53.8 \\
\hline 1991 & 66.9 & 52.8 \\
\hline 1992 & 65 & 51.9 \\
\hline 1993 & 64.6 & 51.5 \\
\hline 1994 & 65.1 & 51.9 \\
\hline 1995 & 65.4 & 52.2 \\
\hline 1996 & 65 & 52.1 \\
\hline 1997 & 65.5 & 52.6 \\
\hline 1998 & 66 & 53.7 \\
\hline 1999 & 66.7 & 54.6 \\
\hline 2000 & 67.3 & 55.4 \\
\hline 2001 & 66.8 & 55.7 \\
\hline 2002 & 67.1 & 56.6 \\
\hline 2003 & 67.6 & 57.5 \\
\hline 2004 & 67.7 & 57.7 \\
\hline 2005 & 67.7 & 57.7 \\
\hline 2006 & 67.6 & 58.1 \\
\hline 2007 & 67.9 & 59 \\
\hline 2008 & 68 & 59 \\
\hline 2009 & 65.1 & 58 \\
\hline 2010 & 65.3 & 57.9 \\
\hline 2011 & 65.7 & 57.8 \\
\hline
\end{tabular}

Source: CANSIM table \#282-0002, Statics Canada. 